\title{
Changing Approaches to Financing and Financial Management in the South African Local Government Sector
}

\section{Sing}

School of Public Administration \& Development Management, University of Natal

\section{ABSTRACT}

Sections 152 and 153 of the Constitution of the Republic of South Africa, 1996 (Act 108 of 1996) have given local government a developmental mandate. Local government has a constitutional obligation to participate in national and provincial development programmes. Local government should become a powerful development catalyst in collaboration with other spheres of government, the non-governmental sector and the local citizenry. It has to address social, economic and infrastructural backlogs and inequalities in a stable and sustainable manner to ensure developmental outcomes are reached. Different financing and financial management policies, strategies, structures, processes and procedures have to be instituted with a view to transformation and innovation. Constant and consistent monitoring, analysis and evaluation of these policies, strategies structures, processes and procedures should ensure these constitutional imperatives.

JEL H71, H72, H77

\section{INTRODUCTION}

Sections 152 and 153 of the Constitution of the Republic of South Africa, 1996 (Act 108 of 1996) (hereafter referred to as the Constitution) mandate the development role and responsibility of the local government sphere and also oblige it to participate in national and provincial development programmes. Existing and pending legislation views the local government sphere as a powerful development agency. According to Parnell and Pieterse (2002: 79) developmental local government as an official policy objective presents the first sign that a new wave of post-apartheid reconstruction is beginning. For local government to perform a development role in addressing social, economic and infrastructural backlogs and inequalities in a viable and sustainable manner, 
innovative and transformative financing and financial management policies, strategies, structures, processes and procedures have to be instituted.

\section{NATIONAL TRANSFERS}

In their discussion of intergovernmental financial relations, official National Government documents distinguish between the different types of grants, agency payments and other forms of national transfers to support national priorities.

A conditional grant is an allocation from one sphere of government to another, subject to the delivery of certain services or compliance with specified requirements (Medium Term Budget Policy Statement (Medium Term BPS), 1998: 78). Conditional grant programmes, which apply to municipalities, are administered by a variety of national departments including Provincial and Local Government, the National Treasury, Water Affairs and Forestry, Transport and Public Works. Such conditional grant programmes are the Consolidated Municipal Infrastructure Programme (CMIP), the Local Economic Development Fund (LEDF), the Community Water and Sanitation Services Programme (CWSSP), the Community Based Public Works Programmes (CBPWP), the South African Housing Fund, the National Electrification Fund, and the Urban Transport Fund. In addition, small infrastructure transfers, mainly in the form of asset transfers, such as those linked to the settlement and land acquisition grant managed by Department of Land Affairs (Intergovernmental Fiscal Review (IFR), 2000: 141-42).

Agency payments are payments made by one government department to another in the same or in a different sphere of government for services administered by the department receiving the payment (Medium Term BPS, 1998: 77). Conditional grants and agency payments are designed to provide for national priorities in the budgets of municipalities. Those payments promote national norms and standards and support local government transition by funding capacity building and restructuring. Such grants also aim to address backlogs and regional disparities in social transformation (IFR, 2000: 133). Section 227 (1)(b) of the Constitution makes provision for local government to receive conditional or unconditional grants from national government revenue.

The equitable share vertical transfer to the local government sector is a Constitutional entitlement in terms of Section 227(1)(a) of the Constitution and is regarded as an unconditional transfer to assist municipalities in providing basic services and performing their assigned functions. The equitable share is administered by the Department of Provincial and Local Government and is a 
sub-programme of the Institutional Reform and Support Programme. The formula-driven horizontal distribution methodology attempts to ensure a greater equity in the allocations to local authorities. These allocations are determined in terms of a policy framework (National Expenditure Survey, 2000: 15).

The formula for distributing equitable share between municipalities has two components: the I grant supports municipalities with limited capacity and the S grant supports all municipalities in the delivery of a basic level of service. The formula has strong poverty bias and attempts to measure the number of povertystricken households. It favours poor rural households, and has reduced allocations to large metropolitan municipalities (IFR, 2000: 122). The predictability of these transfers will be addressed through three-year allocations. Their targeting will be improved through refining the data used in identifying poor households (IFR, 2000: 110). Formula-based direct, horizontal distribution of equitable share transfers to municipalities promotes uniformity and predictability. This distribution also prevents manipulation and perverse allocation incentives such as emergency support and the historical pattern of expenditure (The Introduction of Equitable Share of Nationally Raised Revenue for Local Government, 1998: 5).

\section{FINANCIAL MUNICIPAL INFRASTRUCTURE}

The White Paper on Local Government (1998: 111-12) emphasizes that the system of municipal finance has to include a number of basic policy principles to meet the objectives of the Constitution. One of the policy principles stresses that an increase in investment in municipal infrastructure is required to meet the basic needs of service backlogs. A major role of the Department of Local and Provincial Government is its partnership with local government and the provision of structured support to municipalities for successful delivery. Consolidated Municipal Infrastructure Programme (CMIP) is such a support system and is regarded as a critical part of redistribution funding to the local government sector (IFR, 2000: 104).

The CMIP is operated by the Department of Provincial and Local Government and is a sub-programme of its Governance and Development Programme. The programme funds the creation, extension, upgrading or rehabilitation of internal bulk, connector and internal infrastructure and community services for lowincome households (IFR, 2000: 141). Projects include water and sanitation services, roads, storm-water infrastructure, solid waste disposal and community services. Projects typically involve local contractors and are labour intensive, targeting women, and youths for employment and training (Estimates of National Expenditure, 2002: 106). 
Like all requests for conditional grant funding, the application procedures are stringent and thorough. Funding is provided to municipalities through the submission of an application for project assistance to the Provincial Government. This includes a municipal council resolution approving each project. The Provincial Government prioritizes applications and informs municipalities with the highest priorities to prepare business plans. These business plans are again prioritized and submitted to the Provincial Executive Council for approval. They are then submitted to the Department of Provincial and Local Government, which, if satisfied that all requirements have been fulfilled, recommends funding for the projects (IFR, 2000: 141).

\section{FINANCING LOCAL ECONOMIC DEVELOPMENT}

The fundamentals for a development-orientated local government are set out in Section 195 (1)(c) of the Constitution. Development-orientated local government is regarded as a principle and a value underlying public administration in South Africa. The focus on economic development is set out in Section 152(1)(c) of the Constitution as one of the objectives of local government.

As far as the National Government is concerned, local economic development is no longer reserved for the national and provincial spheres of government. Local authorities can help stimulate the economy and improve the lives of their citizens, thus engaging in Local Economic Development (LED), by utilizing the unique powers and objectives of local government, and working in partnership with community stakeholders (The Local Authority's Role in Economic Development, 1998: 1).

LED is multi-dimensional. It aims to create and retain employment opportunities for local residents, alleviate poverty and distribute resources and opportunities to benefit all local residents. LED can stimulate large and small enterprises within a locality. A municipality can support LED by providing direct economic services such as the provision of business facilities, the promotion of agri-industry, support to tourism initiatives and human resources development programmes (Local Economic Development Fund: Year 20002001 Announcement, 2000: 2). Government support for LED is enabled through the institution of the Local Economic Development Fund (LEDF), which is a sub-programme within the Department of Provincial and Local Government's Governance and Development Programme (National Expenditure Survey, 2000: 20). 
The Department of Provincial and Local Government has developed an application form for municipalities to facilitate the approval of funds. Municipalities have to provide information on the location of, and main access routes to the project. A business plan, a project description and information about the estimated duration of the project, project sectors, sustainability, as well as the direct and indirect beneficiaries of the project, are required. Information about sustainability has direct financial and management implications for a project. The questions include :

- Who will be responsible for the operations and maintenance costs of the projects over the next three to five years?

- What management structures will be in place to facilitate the project?

- Should the project require further finances over the next three to five years, who or what will be the source of such finances?

- What role will the municipality play?

\section{MUNICIPAL INFRASTRUCTURE INVESTMENT UNIT}

The Municipal Infrastructure Investment Unit (MIIU) was established on 20 March 1998 as a non-profit company incorporated under Section 21 of the Companies Act, 1973 (Act 61 of 1973). It reports to the Minister of Provincial and Local Government and is a sub-programme of the Governance and Development Programme of the Department. The company was established as a five-year intervention to develop a market for technical assistance on project preparation in the sphere of municipal infrastructure and services (Annual Report MIIU, 1999: Corporate Profile). The objectives of MIIU are twofold. The first objective is to encourage and optimise private sector investment in core local authority services on a basis that is sustainable at local and national level. The second objective is to assist the development of an established market containing informed local authority clients, private sector advisers, private sector investors and service providers (Estimates of National Expenditure, 2002: 112). Private sector investment can take any of a broad range of forms, including:

- Private sector financing of municipal debt.

- Contracting out of the management of ongoing services.

- Concessions to operate the local authority's assets over a defined period.

- Contracts requiring the private sector to design, build, finance and operate assets to deliver services for the local authority.

- Privatisation of assets and services (Annual Report, MIIU 1999: Corporate Profile). 
For the MIIU to function as a company capable of responding to the demands of local government and the related legal and regulatory environment, various procedures and documents have been established and designed (Annual Report, MIIU 1999: Corporate Profile). The documents and procedures include:

- Applications and approval procedures.

- Procurement and contracting procedures.

- An application questionnaire.

- A project preparation report.

- A grant agreement.

- Cost-sharing guidelines.

- Terms of reference.

- Requests for proposals.

- Newspaper advertisements.

- A consulting contract.

The Grant Funding Application Questionnaire is a comprehensive document which requires qualitative and quantitative information on the infrastructure and existing system of delivery (Annual Report MIIU 1999: Corporate Profile). The questionnaire consists of two sections. Section A, deals with project information and focuses on project identification, project justification and project preparations. Section B, the National Ring-Fencing Exercise concentrates on cost information, debt information, revenue information, tariff information, service coverage information and information on future investment needs.

The Grant Funding Application Questionnaire is also linked to other documents such as the grant agreement and cost-sharing guidelines. The grant agreement is an agreement between a municipality and the MIIU. It provides a description of the project, the terms of reference for the work to be undertaken, as well as the roles and responsibilities regarding project supervision, information sharing and disbursement procedures. The cost-sharing guidelines focus on the sharing of project preparation costs between the MIIU and a municipality (Annual Report MIIU, 1999: Corporate Profile). The preamble to the Questionnaire stipulates that the MIIU portion of the cost share will be based on economic need, previous expenditures, project and financial or technical sustainability. In general, the MIIU will reduce its share in the later stages of the project.

\section{PROJECT VIABILITY PROGRAMME}

Project viability is the responsibility of the Department of Provincial and Local Government and was launched in 1995 (by the then Department of 
Constitutional Development) (Project Viability, 1998: 2). It is sub-programme of the Institutional Reform and Support Programme of the Department (Estimates of National Expenditure, 2002: 106). It is regarded as a national intervention programme which aims at building the financial, administrative and management capacity of financially compromised municipalities in order to make them financially viable. The programme focuses on:

- Monitoring the financial position of municipalities on a quarterly basis.

- Conducting management audits in municipalities that have financial difficulties based on the results of the quarterly survey. The objective is to identify the cause of the problem and determine the level of support required by those municipalities.

- Instituting management support programmes in municipalities that are experiencing financial difficulties.

- Implementing a training and mentoring programme (Department of Constitutional Development, Annual Report, 1998: 61).

Project Viability is then a multi-dimensional management tool which uses the questionnaire to collect data as illustrated in Questionnaire 23. The Questionnaire includes both financial and non-financial indicators. It is divided into sections and sub-sections and requires municipalities to provide information relating to:

- Corporate governance.

- Capacity to deliver services.

- Consumer management.

- Management information systems.

- Audited financial statements.

- Current financial situation.

- Current financial results.

- Analysis of cash flow.

- Analysis of bank investments.

- Analysis of account receivable.

- Analysis of accounts payable.

- Risk management.

- Performance improvement.

- Key statistics and indicators.

- Summary of latest audited financial statements.

- Rates, taxes, service suppliers and levels for domestic consumers.

Reports based on this questionnaire enable the Department to institute a combination of strategic and operational measures to restore the financial health of municipalities. These measures include improving credit control, promoting 
alternative service delivery mechanisms, performance management systems and performance contracts, organizational redesign, improving accounting practices and promoting economic development (IFR, 2000: 101).

At the initial stages of Project Viability, questionnaires were completed voluntarily. However, during 1997, the Minister promulgated regulations which made it mandatory for the chief executive officers of municipalities to provide the Minister or a designated institution, with the necessary information to determine the soundness of a municipality's finances within 21 days. In certain circumstances the relevant Member of the Executive Committee (MEC) may grant exemption from this requirement (Department of Constitutional Development, Annual Report, 1998: 2).

\section{TRANSFORMING AND REFORMING MUNICIPAL BUDGETS}

The National Government has prioritized transforming and reforming budget formats, budget preparation, implementation, monitoring and reporting within the local sphere of government in order to enable municipalities to meet their constitutionally-determined developmental role and responsibilities (IFR, 2000: 116).

Section 215 of the Constitution mandates the National Treasury to prescribe the form and format of municipal budgets as well as the budgetary processes. Furthermore, it must prescribe the information that should be included therein (Local Government Budget Reforms, 1999: 1). As with other aspects of government, municipal budgets have to be governed by the basic values and principles that are contained in Chapter 10 of the Constitution. These include for example, promoting efficient, effective and economical use of resources, transparency, public accountability, public participation and a development orientation.

In order for National Treasury to meet its constitutional obligations relating to municipal budgets, a budget reform project was commissioned. The executive summary of the report and annexures adopted the following framework for its recommendations:

- Encouraging the development role and responsibilities of municipalities.

- Formalising the role of the Department of Finance (now National Treasury) in the budgetary and monitoring processes.

- Encouraging community participation in the budgetary process.

- Facilitating financial management and informed decision making through budget preparation and monitoring processes. 
- Specifying the minimum content that constitutes a municipal budget.

- Instituting appropriate monitoring processes to identify deviations from the budget and financial impact of such deviations on fiscal performance.

- Reflecting economic realities of each municipality.

- Complying with certain information requirements to meet certain international reporting protocols.

- Considering performance management as a part of the budgeting process (Local Government Budget Reforms, 1999: 1-2).

To give effect to these recommendations several annexures were developed to obtain meaningful and usable information. Some of the information that must be detailed includes operating and capital expenditure, municipal budget framework, a summary of the integrated development plan and budget process (Local Government Budget Reforms, 1999: 8-39).

The information requirements set out in the various annexures serve as instruments of budge transformation and reform and enhance the role of the National Treasury in meeting its constitutional obligations. They particularly aim to establish an enabling framework for ensuring that:

- Three-year municipal operating and capital budgets are prepared as in national and provincial spheres of government.

- There is simplification and allocation certainty in the national and provincial grants, on a three-year basis.

- Municipalities have a three-year grant system.

- All revenues and expenditure are accurately shown on the budgets.

- There is a greater involvement by council, the executive and citizens in the budget preparation process.

- The quality of budgets presented to councils is improved to ensure a better understanding by the general public of the trade-offs between different provinces.

- Budgets contain meaningful information to encourage reporting against set objectives and performance indicators.

- An in-year reporting system for early diagnosis of financial problem exists, so that appropriate support programmes can be implemented.

- Comparisons between municipalities are encouraged and general benchmarks are generated through standardised uniform budget formats.

- A standard accounting and reporting system is introduced. Standard classifications for revenue and expenditure in a uniform chart of accounts will allow for benchmarking so that South African municipalities can be compared with one another and with similar municipalities globally (IFR, 2000: 113-17). 


\section{SHIFTING THE PARADIGM IN ACCOUNTING POLICIES, STANDARDS AND PRACTICES}

In terms of Section 216(1) of the Constitution, the National Treasury is required to develop and prescribe generally recognised accounting standards and practices for all spheres of government. Generally Accepted Municipal Accounting Policies (GAMAP) have been developed for municipalities in accordance with this constitutional requirement (An introductory guide to GAMAP, 1999: 1).

The White Paper on Local Government (1998: 125) recommends applying accounting policies, standards and practices specifically tailored for municipalities to address shortcomings in existing municipal accounting practices. Current practices based on the different provincial ordinances are complex. They encourage taxation in advance of need, and adversely affect the accurate costing of services and do not promote transparency. The financial statements of municipalities therefore do not portray their financial position accurately, limiting access to external loans and other finance for essential development in municipalities (Letter to the Holder of the Handbook for Municipal Finance Officers, Institute of Municipal Finance Officers, 28 October 1999). The aim of GAMAP is not to regulate transactions of a municipality through legislation. It merely aims to ensure that the transactions that a municipality has entered into are disclosed in the financial statements, regardless of whether such transactions are legal or illegal. GAMAP require that a municipality disclose transactions in the financial statements in a consistent manner using recognised practices, to enable users to accurately assess operating results, the financial position and the cash flows of municipalities. Municipalities that use the same accounting policies, practices and standards facilitate comparisons between them. GAMAP ensures that South African municipalities use accounting policies, practices and standards that are generally recognised both nationally and internationally, and which apply to both public and private organizations (An introductory guide to GAMAP, 1999: 1-2).

\section{MUNICIPAL FINANCIAL EMERGENCY}

Section 44 of the Constitution read in conjunction with Sections 139 and 155 stipulate that national and provincial governments have legislative and executive authority to ensure that municipalities perform their functions effectively. These measures provide for provincial government intervention and, if this is not done effectively, national government can then intervene in the affairs of municipalities. Failures in the functions of municipalities are often manifest in the development of a financial crises (Policy Framework for Municipal 
Borrowing and Financial Emergencies (Policy Framework for MBFE), 2000: 17).

Existing procedures are complicated and are not necessarily conducive to effective ratification. The reason is that existing constitutional and legal provisions are not entirely optimal, especially with respect to situations where interventions fail to bring about the desired results. In order for such problems to be avoided, a system with clear and effective procedures and authorities is needed. To this end, the National Government has begun a process of establishing a set of procedures, to be authorized by the Judiciary and to be overseen by a Municipal Financial Authority. The purpose of the procedures is to deal with municipalities when, notwithstanding all other interventions, they run into a situation of financial distress (Policy Framework for MBFE, 2000: 120-23).

The Municipal Financial Emergency Authority will be established as a separate institution outside the Public Service and will have a juristic personality. It will have the task of overseeing the administration of financial emergencies in a manner analogous to the Master of the High Court in respect of judicial managements. The Authority will be required to supervise recovery plans for municipalities where a situation of Financial Emergency has been declared by a court order. In order to give effect to the court order the Authority has to promptly appoint an Administrator whose main task will be to develop a recovery plan (Policy Framework for MBFE, 2000: 122-24). The fundamental objectives of the recovery plan will be inter-alia to:

- Restore the municipality to a sound financial and fiscal condition as soon as possible and to restore it creditworthiness.

- Identify the underlying fiscal or financial problems of the municipality.

- Describe a general strategy for addressing these problems.

- Describe the anticipated time framework for recovery, and milestones to be achieved.

- Identify the principal objectives of the plan and methods for achieving those objectives (Policy Framework for MBFE, 2000: 137-38).

The Administrator shall intervene in the affairs of the municipality to the extent appropriate to the municipality's condition, using the least intrusive practical measures and means to effectively address the situation. In a case where a municipality takes necessary actions to the satisfaction of the Administrator, the Administrator need not exercise its powers in-lieu of the municipality. The main objectives of the intervention by the Administrator are to restore fiscal integrity and full democratic governance as soon as possible (Policy Framework for MBFE, 2000: 122). Other implications are that National Government is intent on distancing itself from day-to-day operations of municipalities and that 
National Government will act as a guarantor in case municipalities fail (Pauw et al., 2002: 267-68).

\section{CONCLUSION}

Viability and sustainability are fundamental factors in municipal service delivery if local government is to address its development role effectively. The financing of economic and social development and municipal infrastructure, using appropriate national transfers needs constant and consistent analysis and evaluation. Strategic interventions, such as project viability studies, budget reform and the generally accepted municipal accounting policies, promote a holistic approach to achieving developmental objectives of local government. Policies and procedures for dealing with financial emergencies will ensure that municipalities do not fail in achieving their objectives.

\section{REFERENCES}

1 DEPARTMENT OF CONSTITUTIONAL DEVELOPMENT (1998) Project Viability, Pretoria.

2 DEPARTMENT OF CONSTITUTIONAL DEVELOPMENT (1998) Annual Report, Pretoria.

3 DEPARTMENT OF FINANCE (1999) Local Government Budget Reforms, Executive Summary, Pretoria.

4 DEPARTMENT OF PROVINCIAL AND LOCAL GOVERNMENT (2000-2001) Local Economic Development Fund, Announcement, Pretoria.

5 INSTITUTE OF MUNICIPAL OFFICERS (1999) An Introductory Guide to GAMAP.

6 INSTITUTE OF MUNICIPAL OFFICERS (1999) Letter dated 28 October to Holder of the Handbook for Municipal Finance Officers.

7 MINISTRY OF PROVINCIAL AFFAIRS AND CONSTITUTIONAL DEVELOPMENT (1998) White Paper on Local Government, Pretoria.

8 MUNICIPAL INFRASTRUCTURE INVESTMENT UNIT (1999) Annual Report, Midrand, Halfway House.

9 PARNELL, S. \& PIETERSE, E. (2002) "Developmental local government”, in Parnnel, S. et al. (eds.) Democratising Local Government: The South African Experiment, University of Cape Town Press, Cape Town.

10 PAUW, J.C. et al. (eds.) (2002) Managing Public Money: A System from the South, Heinemann Publishers (Pty) Ltd, Sandown. 
11 REPUBLIC OF SOUTH AFRICA (1996) The Constitution of the Republic of South Africa Act, Act 108 of 1999.

12 REPUBLIC OF SOUTH AFRICA (1998) Medium Term Budget Policy Statement, Department of Finance, Pretoria.

13 REPUBLIC OF SOUTH AFRICA (1998) The Introduction of an Equitable Share of Nationally Raised Revenue for Local Government, Department of Finance, Pretoria.

14 REPUBLIC OF SOUTH AFRICA (2000) "Policy framework for municipal borrowing and financial emergencies", Government Gazette No. 21423, General Notice 2739, 28 July, Pretoria.

15 REPUBLIC OF SOUTH AFRICA (2000) Intergovernmental Fiscal Review, National Treasury, Pretoria.

16 REPUBLIC OF SOUTH AFRICA (2000) National Expenditure Survey, National Treasury, Pretoria.

17 REPUBLIC OF SOUTH AFRICA (2002) Estimates of National Expenditure, National Treasury, Pretoria.

18 THE LOCAL AUTHORITY'S ROLE IN ECONOMIC DEVELOPMENT (1998) A Handbook for Councillors and Officials, International Republican on Institute. 